\title{
Development of Ecocentric-Ecological Consciousness of Students of a Technical University
}

\author{
Raisa Bazaliy ${ }^{1, *}$ \\ ${ }^{1}$ Don State Technical University, Gagarin sq., 1, Rostov on Don, 344003, Russia
}

\begin{abstract}
In the article, the author considers the main trends in the development of ecocentric-ecological consciousness in modern society. The current state has been analyzed as well as the complexity of the development of the ecocentric-ecological consciousness of an individual has been revealed. The increasing amount of scientific literature on the problems of environmental education confirms the relevance of the research topic in modern society. The article substantiates the need to re-profile the ecocentric-ecological consciousness in the education system, the need to retarget the behavior of the young generation to the nature-related sphere, and considers the value aspects of environmental protection activities.
\end{abstract}

\section{Introduction}

At the beginning of the 21st century, the interaction of people and the natural world around them has become an urgent problem that requires appropriate understanding and development of promising areas of socio-ecological cooperation. Modern aspects of the development of post-industrial culture indicate that the complex of technological and environmental problems that form the direction of personal development in society and the instrumental capabilities of civilization are not interconnected to the necessary extent with spiritual and moral factors. The development of ecocentric-ecological consciousness of university students shows the ability to identify the value meanings of the life of modern society and to indicate the consequences of reckless use of natural resources. Innovative research-and-production and educational technologies in many countries are seeking to increase the level of social and environmental development of society in order to reduce the risk of a global environmental catastrophe.

In the modern scientific discourse, the directions of development and reinterpretation of ecological consciousness are discussed: scientists P. W. Schultz, L. C. Zelezny use the concept of ecological consciousness to denote psychological factors associated with the predisposition of individuals to participate in pro-ecological behaviors. Researchers are moving away from a multidimensional and behavior-oriented definition of environmental consciousness. This approach does not include the various types of pro-environmental

\footnotetext{
${ }^{*}$ Corresponding author: rv7bazalii@mail.ru
} 
behavior, other factors, or psychological constructs that are usually associated with them: beliefs, values, attitudes, knowledge, and others. From an analytical point of view, an environmentally conscious individual or pro-ecologist is someone who participates in a wide range of pro-ecological behavior, as well as adheres to certain values and attitudes associated with this type of behavior [1,2]. Scientists M. J. Sánchez, R. Lafuente propose the operationalization of environmental consciousness, which combines the alignment of proenvironmental values and perception of the state of the environment (affective aspect) with the level of information (cognitive aspect), attitudes to action (dispositional aspect) and participation in pro-environmental behaviors (active aspect). Researchers believe that a causal relationship exists between all aspects of environmental consciousness, and that the relationship between the affective aspect and the active aspect (pro-environmental behavior) is mediated by behavioral and cognitive components [3]. R. J. Borden explores the problems of pollution, resource depletion, technological impact, and exponential population growth that have caused a gradual rethinking of human consciousness in understanding our relationship to the living world [4]. L. N de Senerpont Domis, S. Teurlincx recognized the need for a comprehensive assessment of human-ecosystem interaction based on the "One Health» approach [5]. K. J. Bowen, K. L. Ebi formulated the basic requirements for a successful response to the growing health risks, and identified the relationships between people and our natural environment - the health of our planet. The authors identified what actions remain critical to support the restoration of healthy communities that thrive socially, economically, to respect our planet, and to respect and restore ecosystems [6]. F. M. Le Tourneau, C. Scott investigated the resilience and complexity of socio-ecological systems, and determined that the ecosystem could undergo major changes during a climate crisis. It is important not so much to preserve its specific configuration, but to maintain the necessary functioning through broader transformation processes [7]. Listed in the academic discourse, the basic development concept of environmental education and rethinking consciousness of human interaction and natural environment confirm the relevance of the study and the need for conversion ecocentric environmental consciousness in the education system and the activation value of the meanings of nature-oriented activities of students of technical university. The value reorientation of the ecocentric-ecological consciousness of students of a technical university changes the ideas of young people about the nature of the relationship between modern society and the natural resource management sphere, attitudes towards the environment and modern technologies of interaction with it. The current state of the human environment is determined by the level of its spiritual and moral culture, value and semantic directions as well as the state of ecocentric-ecological consciousness. In this regard, the following tasks are important: to explore the features and possibilities of ecocentricecological consciousness and value positions in relation to the nature sphere; to determine the specifics of the manifestation of ecocentric-ecological consciousness at various stages of socio-natural development of university students.

\section{Materials and Methods}

The following methods were used in the study: the study of scientific literature on the topics of environmental education and upbringing, ecocentric-ecological consciousness, environmental conservation. The formation of ecological consciousness of students was diagnosed using the V. A. method. Asvina «The Development of my environmental consciousness»; we have examined the ability of environmental education and upbringing, the influence of life experience in adverse socio-ecological environment on the development features of the ecocentric-ecological consciousness of the individual, the interest of students refocus their behavior to environmental sphere. We used questionnaires, testing, questionnaires, performing socio-environmental contextual tasks, studying the results of 
students environmental activities, and comparing data on the research problem. The results of the study were obtained by a sample of 135 students of DSTU, 87 of them are trained in technical areas and 48 - in the humanities.

\section{Results and discussion}

Since 2017, each course of technical and humanitarian areas has been taught pedagogical disciplines «Philosophy and History of Education», «Methods of educational work», the content of which expands the process of forming environmental culture and the formation of environmental consciousness of students. The results of the study were analyzed in 2021, effective pedagogical technologies and educational and information resources of the Internet, forms and means of improving the perception of the ecological and methodological orientation of the educational and information environment of the university were identified. The spiritually oriented paradigm of education helps students to realize the existence of a single ecological system, to consider from a spiritual and moral position the factors of the development of the ecocentric-ecological consciousness of the individual. Knowledge of the main trends and patterns of development of ecocivilization, the nature of their manifestation in the educational process, in ecological culture reflects the world trends. The global problems of our time have caused the need to strengthen environmental education, designed to implement the ways of harmonious interaction between society and nature.

Currently, the adoption of environmental ideas in education is actively discussed, which is reflected in the works of specialists in the field of ecology. Researchers K. S. Bakirova, S. Ainur analyze the features of methods and forms of teaching environmental disciplines, we are called upon to form a system of scientific knowledge, views and valuable ideas among students that the danger of an impending environmental disaster can be prevented only by immediate and radically improved environmental measures [8]. The environmental activities carried out at the technical university, the implementation of environmental activities by students, confirm their possession of a set of environmental skills that a person can master during special training. For us, the results of the study by S. K. Singh, J. Chen, M. D. Giudice, A-N. El-Kassar are important, which show that environmental ethics affects environmental learning, environmental performance, and competitive advantage. Environmental training of employees mediates the impact of environmental ethics on the environmental performance and competitive advantages of the company. The results of the study suggest that the organizational approach to the practice of environmental ethics in the workplace should not be reactive, but proactive, with the intention of creating and maintaining synergies between the triads, namely profit, society and the environment.

Environmental training should not be a one-time event, but a continuous process that allows you to surpass competitions and improve environmental performance in the organization [9]. W. Zhou argues that only a dialogue linking science, aesthetics and axiology can solve the moral problems of the environmental crisis, the scientist suggests seriously thinking about raising bioecological awareness and resolving the environmental crisis [10]. S. Otto, G. Evans, M. Moon, F. Kaiser noted the importance of developing environmental attitudes and behavior of students [11], E. Kallas, T. Solovjeva, L. Minakova justified the need for environmentally sound education in connection with global environmental problems [12], S. Findlow advocates environmental concepts and social transformations as the basis of environmental sustainability [13], H. Hwang noted the impact of the environmental context of teacher education [14], N. Ardoin, A. Bowers, and E. Gaillard investigated the contribution of environmental education to the preservation and quality of the environment [15]. For the solution of psychological and pedagogical components of these problems requires the development of ecological education of students of technical university and awareness of the causal relationship between the environmental challenges to successful conservation 
activities of students, creation of favorable conditions for the manifestation of ecocentric environmental consciousness at various levels of socio-natural development of students of human transformation of social-ecological systems.

In the scientific world, the works of scientists of the psychological and pedagogical plan are presented, analyzing the role of the value components of environmental consciousness in the system of education and upbringing. A. K. Saxena, D. Chatti, R. Overstreet and M. R. Dove emphasize that human ecology, especially developed on the basis of qualitative research, has long considered the environment from the point of view of relations. For our research, it is important that the use of and interaction with environmental resources by human communities is determined by social values, which sometimes outweigh economic problems; and that value systems related to the environment are not static or isolated from broader structures of cultural values [16]. E. Grubert investigated relative values in environmental assessment, determined the impact of the social context on the environment. The scientist argues that environmental impacts are mediated by relational values, which have a great influence on how impacts are experienced, the processes of environmental assessment. According to the author, it is now important to include social values in the environmental assessment tools [17]. M. H. Hansen analyzes media representations of ecocivilization in order to find out what values and views a highly professional state project entails. The article argues that ecocivilization is best understood as a sociotechnical imaginary, in which cultural and moral virtues constitute key components, inseparable from more well-known technological, legal, and political goals. The imaginary eco-civilization seeks to create a sense of cultural and national continuity, promoted as a vision of a society characterized by environmentally sustainable ways of resource extraction, production and trade, in which environmentally conscious and responsible citizens live [18]. The importance of ecocentric traditions, the idea of inner harmony between humanity and nature is important for the manifestation of the possibilities of ecocentric-ecological consciousness of students of the technical university, value positions in relation to the nature sphere.

Value aspects receive significant coverage in the development of socio-natural strategies for the development of ecocivilization. B. W. Haas believes that the worldview in human relations with the natural world plays an important role in psychological health. The scientist explores how the worldview about nature is related to psychological health during a serious natural disaster and how this relationship may differ depending on the cultural context. $\mathrm{He}$ presents the results of a study confirming that culture softens the connection between the worldview of domination over nature and negative emotions [19]. When implementing educational activities with the use of eco-oriented pedagogical technologies for the development of ecocentric-ecological consciousness of students, it is important to identify cultural values and fundamental ideological attitudes of environmental education and upbringing that meet the requirements that are put forward to the individual in the context of the aggravation of modern environmental problems. For our research, the approaches indicated by scientists to the successful formation of the ecological consciousness of the individual, the classification of its types and trends in the effective development of the environment are important.

Table 1. Types of environmental awareness.

\begin{tabular}{|l|l|l|}
\hline & \multicolumn{3}{|c|}{ Approaches and actions } \\
\hline $\begin{array}{l}\text { syncretic } \\
\text { ecological } \\
\text { consciousness }\end{array}$ & $\begin{array}{l}\text { a person in his consciousness and } \\
\text { self-consciousness does no individual, relying on his } \\
\text { distinguish himself from the }\end{array}$ & $\begin{array}{l}\text { own survival goals, does not } \\
\text { oppose the environment as an } \\
\text { object of confrontation }\end{array}$ \\
\hline surrounding world of nature & $\begin{array}{l}\text { man is opposed to the environment, } \\
\text { this approach has caused an }\end{array}$ & $\begin{array}{l}\text { the personality considers the } \\
\text { natural world as an object of }\end{array}$ \\
\hline
\end{tabular}




\begin{tabular}{|l|l|l|}
\hline $\begin{array}{l}\text { ecological } \\
\text { consciousness }\end{array}$ & $\begin{array}{l}\text { environmental crisis on a global } \\
\text { scale }\end{array}$ & $\begin{array}{l}\text { activity transformation based } \\
\text { on individual survival goals }\end{array}$ \\
\hline $\begin{array}{l}\text { ecocentric } \\
\text { environmental } \\
\text { awareness }\end{array}$ & $\begin{array}{l}\text { the individual is aware of his place in } \\
\text { the natural environment around him } \\
\text { as part of a single ecosystem. The } \\
\text { eco-environment becomes the sphere } \\
\text { of a person's co-existence with } \\
\text { nature, which has the self-worth of } \\
\text { its existence }\end{array}$ & $\begin{array}{l}\text { account the right of the } \\
\text { acological environment to its } \\
\text { own patterns of development }\end{array}$ \\
\hline $\begin{array}{l}\text { energeticheskoe } \\
\text { environmental } \\
\text { awareness }\end{array}$ & $\begin{array}{l}\text { the individual is aware of the unity } \\
\text { with nature as the unity of the } \\
\text { principles of self-development with } \\
\text { the universal principles of the } \\
\text { development of the natural world }\end{array}$ & $\begin{array}{l}\text { ensential part of the ecological } \\
\text { environment. Nature preserves } \\
\text { the capacity for self- } \\
\text { generation, self-preservation, } \\
\text { and self-destruction }\end{array}$ \\
\hline
\end{tabular}

Joining the environmental activities through the inclusion of students of the technical university in the university life, 40 students of technical and 22-humanitarian areas of the 1st year in the course of the survey noted the following components of environmental culture: showing interest in environmental problems-39\%, the ability to protect the environment$42 \%$, - responsible behavior towards nature- $19 \%$. Analyzing the responses of 354 th-year bachelors, we found a difference in the respondents ideas about environmental culture: $27 \%$ noted the knowledge of the rules that create harmony in nature, $45 \%$ - the desire to cooperate with volunteer environmental groups, and $28 \%$ - the moral attitude to the environment. A comparison of the survey results showed that the awareness of environmental protection activities, practical environmental skills, the formation of environmental needs and knowledge among students of the 1st and 4th courses differ. It can be concluded that it is necessary to modernize the organizational and content aspects of environmental education and upbringing, which ensures the formation of environmental beliefs and the development of ecocentric-ecological consciousness of students of the technical university.

In our study, studying pedagogical disciplines, students of technical and humanitarian fields strive to realize universal competencies, to understand their attitude to environmental protection activities. Performing socio-environmental contextual tasks related to the identification of the causes of the increased number of man-made disasters and natural disasters in the last two decades, the respondents identified: an increase in aggression and crime - $39 \%$, the complexity of socio-psychological conditions - $27 \%$, the lack of psychological and pedagogical preparation of the individual for life in extreme conditions $34 \%$. As subjects of the ecological development process, students are aware of themselves as key elements of a single ecological system. Under the current conditions, the ecological environment acts as a means of developing natural opportunities for them, students act in relation to the surrounding nature as a means of its self-development and try to develop their natural qualities.

The socio-ecological approach to students is provided by modern technologies of the information and educational environment of the technical university and the logic of the organization of the educational process, which corresponds to the laws of the development of the ecological culture of students. The tendency to improve the information and methodological orientation of the educational environment contributes to the development of ecocentric-ecological consciousness and is confirmed by scientific publications. For example, F. H. Besthorn examines the paradigm shift in environmental practice in recent decades: a new environmental model has emerged that argues that the core values of social work and its traditional environmental models must be changed to support the new realities 
of the importance of the natural environment and the impending environmental crisis. The researcher traces the historical evolution of the traditional ecological thinking of social work and outlines the contours of the new ecology of social work [20]. For our study important of these values of social work, the younger generation technical university is taking part in socio-environmental events and trainings, the successful implementation of ecological and pedagogical task contributes to the development of ecocentric environmental consciousness, repurposing behavior of the students to the environmental sector and acceptance of responsibility for the natural development of the entire community.

In modern times, the economic activity of people has become the main source of pollution of the natural environment. Various chemicals found in gaseous, liquid and solid waste products enter water, soil, air, and the human body. Scientists have discovered toxic substances of modern production, an increased concentration of pollutants in the ice of Antarctica. Substances that pollute the natural environment are brought here by atmospheric currents from other continents. They can cause adverse effects on the body of polar explorers living on scientific stations, although there are no industrial production facilities.

During the testing of students of 3-4 courses: 47-technical areas, 26-humanities, questions were asked related to the impact of human economic activity on the biosphere, rules were defined that focus on the reasonable use of the country's natural resources and the protection of the environment from various types of pollution. The respondents identified the following problems of rational use of natural resources, suggested possible cooperation processes and rules of attitude to the environment that will help to mitigate the merciless exploitation of nature, create favorable conditions for the life of humanity.

Table 2. Problems of rational use of natural resources.

\begin{tabular}{|c|c|c|}
\hline \multicolumn{2}{|c|}{ processes that solve the problems created } & \multirow{2}{*}{$\begin{array}{c}\text { suggestions that create an optimal } \\
\text { environment }\end{array}$} \\
\hline water resources & soil resources & \\
\hline $\begin{array}{l}\text { use of single-stage } \\
\text { production processes } \\
\text { instead of multi-stage } \\
\text { ones }\end{array}$ & $\begin{array}{l}\text { deforestation due to } \\
\text { increased demand } \\
\text { for wood fuel }\end{array}$ & $\begin{array}{l}\text { restore control over the activities of } \\
\text { corporations engaged in deforestation - } \\
\text { reduce the destruction of hundreds of } \\
\text { hectares of trees }\end{array}$ \\
\hline $\begin{array}{l}\text { transition from liquid } \\
\text { to gas processing } \\
\text { processes }\end{array}$ & $\begin{array}{l}\text { destruction of } \\
\text { perennial plants }\end{array}$ & $\begin{array}{l}\text { use public transport - will significantly } \\
\text { reduce gas emissions }\end{array}$ \\
\hline $\begin{array}{l}\text { replacing industrial } \\
\text { water with other } \\
\text { solvents }\end{array}$ & $\begin{array}{lr}\text { use of } & \text { excessive } \\
\text { amounts } & \text { of } \\
\text { pesticides } & \text { and } \\
\text { fertilizers } & \\
\end{array}$ & $\begin{array}{l}\text { increase the number of treatment } \\
\text { facilities - there is a shortage of water }\end{array}$ \\
\hline $\begin{array}{lrr}\begin{array}{l}\text { extraction } \\
\text { substances } \\
\text { wastewater }\end{array} & \begin{array}{r}\text { useful } \\
\text { from }\end{array} \\
\end{array}$ & $\begin{array}{l}\text { activation of soil } \\
\text { salinization }\end{array}$ & $\begin{array}{l}\text { hand over the battery for recycling- } \\
\text { saves several cubic meters of soil from } \\
\text { contamination }\end{array}$ \\
\hline $\begin{array}{ll}\text { transfer of industrial } \\
\text { enterprises to waste- } \\
\text { free } & \text { production } \\
\text { technology } & \end{array}$ & $\begin{array}{l}\text { preventing the } \\
\text { threat of total lack } \\
\text { of oxygen }\end{array}$ & $\begin{array}{l}\text { to create wildlife sanctuaries, nature } \\
\text { reserves and national parks }\end{array}$ \\
\hline $\begin{array}{l}\text { transition to integrated } \\
\text { processing of raw } \\
\text { materials }\end{array}$ & $\begin{array}{l}\text { degradation and } \\
\text { reduction of forest } \\
\text { areas }\end{array}$ & $\begin{array}{l}\text { do not throw a plastic bag on the beach } \\
\text { - it can cross the ocean and kill a } \\
\text { seabird off the coast of another } \\
\text { continent }\end{array}$ \\
\hline
\end{tabular}

The results of our testing confirmed the scientists thoughts that increasing the pace of industrial production negatively affects the state of the environment, and valuable resources 
are exchanged for waste and toxic substances that cannot be disposed of. To reduce the negative impacts on natural resources, eliminate the threat to human existence, the entire ecosystem of the planet, a rational approach to nature management and environmental protection is necessary. The conclusions made by the author are confirmed by the research of G. G. Parfilova, A. M. Kalimullin. Scientists have studied the formation of environmental competence of university students with the totality of all its components. Based on the results obtained, recommendations are given for the organization of special psychological and pedagogical work to improve the level of environmental competence of students [21]. Students of the technical university, developing universal competencies, analyze ready-made environmental solutions that enterprises will be able to implement and use for the preservation of the environmental sphere.

Environmental problems should be solved by the efforts of all mankind and actively eliminated by the efforts of an environmentally educated young generation. Undergraduates were asked to analyze the situation: «Why do some people think that the problem of environmental protection is not directly related to them?». The survey of students revealed a widespread opinion that the air, water and soil are polluted by enterprises and factories, animals are destroyed by poachers, and humans have nothing to do with actions that destroy the nature sphere. Respondents noted that each of us does things every day that harm or help the cause of preserving the environment. People forget that the protection of the environment depends on each of us, and we are able to protect nature from destruction and destruction.

The environmental volunteers interviewed by us believe that everyone needs to reconsider their own views on the preservation and protection of the surrounding world, pay attention to habits and think about which of them are safe and dangerous for nature, and try to make a significant contribution to the protection of the nature protection sphere. Ecologists of the student volunteer movement direct their environmental actions to the creation of renewable energy sources, the purification of water bodies and the atmosphere, the preservation of forests, the overcoming of various local environmental problems, and the recycling of raw materials. The environmental activities of the environmental organization of the Don State Technical University help to increase interest in the purification of the native land and increase the overall level of environmental cleanliness in the Southern region, limit fishing to preserve endangered species in the Don River and clear the floodplain of the river, introduce new fishing methods that cause minimal harm to the environment.

The university's youth environmental teams take an active part in the social project «Ecology of the Spirit - Ecology of life», aimed at forming ecological thinking and personal spiritual and moral motivation of students in environmental activities, educating the younger generation of the ecological culture of handling natural wealth, as well as creating and developing park areas in the city of Rostov-on-Don. The Russian online platform of the agroindustrial complex «Golden Autumn» conducts socio-ecological seminars for scientists and students of the technical university of various environmental areas. For example, the series «Techniques and technologies of treatment with plant

protection products for soil protection and resource-saving agriculture» raises current economic and environmental problems that lead to crop shortages, significant overspending of fertilizers, damage to the environment, and an increase in nitrates in agricultural products.

Environmental problems in the world are created by man, not by nature, so many of the questions posed by the crisis of the environment are answered in the human soul, and not only in the fields of technology or economics. In this regard, the technical university has created an ecological and methodological orientation of the educational process that contributes to the preservation and revival of ecology, helps students to improve moral relations with nature, activate the nature-saving activities of students and predict the likely consequences of various human actions in nature. 


\section{Conclusion}

The study has confirmed the importance of environmental education and upbringing in the development and implementation of interactive teaching methods for the development of ecocentric-ecological consciousness of students of a technical university. In the modern world, there is a need to protect the environmental sphere from the destructive impact of a technocratic society, and for this, people must think and act as subjects of a single ecological system. The solution of this problem requires the re-profiling of ecocentric-ecological consciousness in the education system to preserve the interconnected ecological system, retargeting the behavior of the younger generation to the nature-related sphere and the preservation of environmental resources as a living environment.

The introduction of modern pedagogical technologies for the development of ecocentricecological consciousness of the younger generation in the education system leads to a tendency to expand the environmental activities of students, to participate actively in student volunteer and environmental movements that improve individual protection of a person from traumatic effects when the environment is polluted. According to the ecological imperative, by interacting with natural objects correctly, without disturbing the ecological balance that exists in nature, students of a technical university successfully overcome the risks associated with the global environmental crisis.

\section{References}

1. W. Schultz, Environmental Psychology 24, 31-42 (2014)

2. L. Zelezny, Social Issues 56, 365-578 (2015)

3. M. Sánchez, R. Lafuente, Revista Internacional de Sociología (RIS) 68, 731-755 (2017)

4. R. Borden, Current Opinion in Environmental Sustainability 25, 45-49 (2017) doi.org/10.1016/j.cosust.2017.07.006

5. L. Senerpont Domis, S. Teurlincx, Current Opinion in Environmental Sustainability 20, 1-3 (2019) doi.org/10.1016/j.cosust.2020.10.008

6. K. Bowen, K. Ebi, Current Opinion in Environmental Sustainability 12, 1-2 (2019) doi.org/10.1016/j.cosust.2020.10.002

7. F.-M. Tourneau, C. Scott, Current Opinion in Environmental Sustainability 44, 1-3 (2020) doi.org/10.1016/j.cosust.2020.10.010

8. K. Bakirova, S. Ainur, Procedia - Social and Behavioral Sciences 141, 543 - 545 (2014) doi.org/10.1016/j.sbspro.2014.05.094

9. S. Singh, J. Chen, M. Giudice, A.-N. Kassar, Technological Forecasting \& Social Change 146, 203-211 (2019) doi.org/10.1016/j.techfore.2019.05.032

10. W. Zhou, Language Sciences 62, 124-138 doi.org/10.1016/j.langsci.2017.04.004

11. S. Otto, G. Evans, M. Moon, F. Kaiser, Global Environmental Change 58, 101947 (2019) doi.org/10.1016/j.gloenvcha.2019.101947

12. E. Kallas, T. Solovjeva, L. Minakova, Procedia - Social and Behavioral Sciences 200, $453-459$ (2015) doi.org/10.1016/j.sbspro.2015.08.095

13. S. Findlow, Ecological Economics 157, 373-381 doi.org/10.1016/j.ecolecon.2018.11.020

14. H. Hwang, Teaching and Teacher Education 43, 1-14 (2014) doi.org/10.1016/j.tate.2014.05.003 
15. N. Ardoin, A. Bowers, E. Gaillard, Biological Conservation 241, 108224 (2020) doi.org/10.1016/j.biocon.2019.108224

16. A. Saxena, D. Chatti, K. Overstreet, M. Dove, Current Opinion in Environmental Sustainability 35, 54-60 (2018) doi.org/10.1016/j.cosust.2018.10.021

17. E. Grubert, Current Opinion in Environmental Sustainability 35, 100-107 (2018) doi.org/10.1016/j.cosust.2018.10.020

18. M. Hansen, Global Environmental Change 53, 195-203 (2018) doi.org/10.1016/j.gloenvcha.2018.09.014

19. B. Haas, F. Hoeft, K. Omura, Personality and Individual Differences 170, 110336 (2021)

20. F. Besthorn, International Encyclopedia of the Social \& Behavioral Sciences (Second Edition) 871-877 (2015) doi.org/10.1016/B978-0-08-097086-8.28027-6

21. G. Parfilova, A. Kalimullin, Procedia - Social and Behavioral Sciences 131, 35 - 39 (2014) doi.org/10.1016/j.sbspro.2014.04.075 